\title{
Neutral lipid-storage disease with myopathy and Jordan anomaly
}

Riccardo Zuccarino, MD, Daniel M. Anderson, MD, Carol Holman, MD, Shawna Feely, MS, Laurie Gutmann, MD, and Ludwig Gutmann, MD

Neurology ${ }^{\circledR}$ 2020;95:599-600. doi:10.1212/WNL.0000000000010585

\section{Correspondence}

Dr. Zuccarino

riccardozuccarino@yahoo.it

Figure Unstained vacuoles with Giemsa and stained vacuoles with oil red $\mathrm{O}$

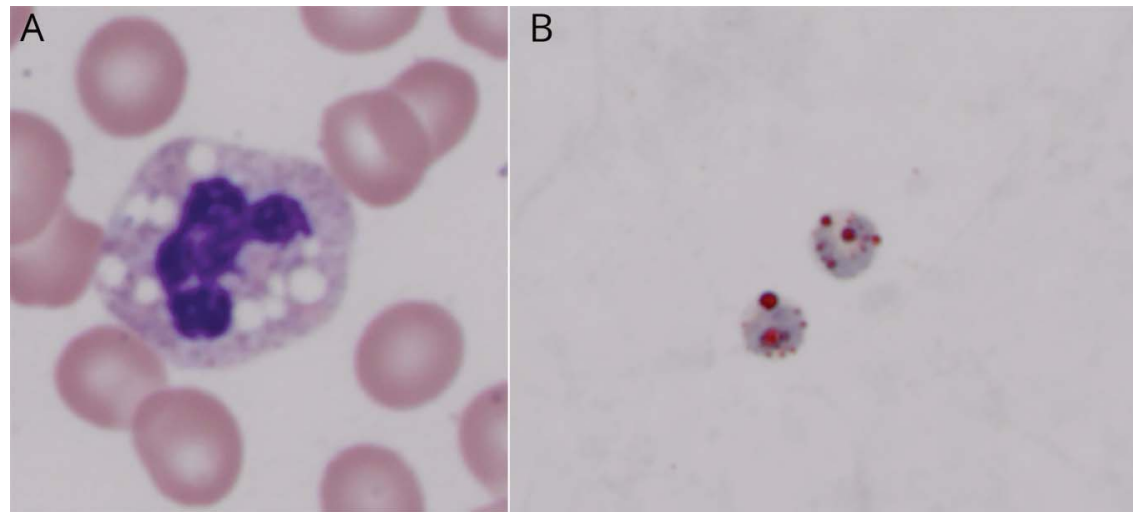

Jordan anomaly can be seen on a peripheral blood smear using the Giemsa method (A) or oil red $O$ (B) staining showing lipid accumulation of neutral triglycerides in vacuoles in leukocytes (pictures were both taken at 100x). All patients reported with neutral lipid storage diseases have this finding. The same is seen in myocytes.

A 58-year-old man presented with slowly progressive weakness involving proximal arm, distal leg, and finger extensor muscles. His history included embolic stroke, cardiomyopathy, diabetes, and triglyceridemia. Family history of myopathy was absent, but consanguinity was present. Muscle biopsy and carnitine/acylcarnitine testing were deferred. Heterozygous mutation in GNE p.V727L (VUS) and homozygous mutations in PNPLA2 p.R221P (pathogenic) were present. PNPLA2 mutations cause neutral lipid storage disease with myopathy $\left(\mathrm{NLSDM}^{1}\right)$ and associated cardiomyopathy, metabolic disorders, and leucocyte vacuoles (figure). Jordan anomaly ${ }^{2}$ (leukocytic triglyceride containing vacuoles) on peripheral blood smear confirmed NLSDM. This is a unique abnormality documenting the pathologic basis for NLSDM.

\section{Study funding}

No targeted funding reported.

\section{Disclosure}

The authors report no disclosures relevant to the manuscript. Go to Neurology.org/N for full disclosures. 
Appendix Authors

\begin{tabular}{|c|c|c|}
\hline Name & Location & Contributions \\
\hline $\begin{array}{l}\text { Riccardo } \\
\text { Zuccarino, } \\
\text { MD }\end{array}$ & $\begin{array}{l}\text { University of Iowa, Iowa } \\
\text { City; Centro Clinico NEMO, } \\
\text { Genoa, Italy }\end{array}$ & $\begin{array}{l}\text { Study concept and design, } \\
\text { analysis and interpretation of } \\
\text { data, drafting and critical } \\
\text { revision of manuscript for } \\
\text { intellectual content }\end{array}$ \\
\hline $\begin{array}{l}\text { Daniel M. } \\
\text { Anderson, } \\
\text { MD }\end{array}$ & $\begin{array}{l}\text { University of lowa, lowa } \\
\text { City; Mayo Clinic Health } \\
\text { System-Franciscan } \\
\text { Healthcare, La Crosse, WI }\end{array}$ & $\begin{array}{l}\text { Study concept and design, } \\
\text { analysis and interpretation of } \\
\text { data, drafting and critical } \\
\text { revision of manuscript for } \\
\text { intellectual content }\end{array}$ \\
\hline $\begin{array}{l}\text { Carol } \\
\text { Holman, } \\
\text { MD }\end{array}$ & $\begin{array}{l}\text { University of lowa, lowa } \\
\text { City }\end{array}$ & $\begin{array}{l}\text { Providing images, critical } \\
\text { revision of manuscript for } \\
\text { intellectual content }\end{array}$ \\
\hline $\begin{array}{l}\text { Shawna } \\
\text { Feely, MS }\end{array}$ & $\begin{array}{l}\text { University of lowa, lowa } \\
\text { City }\end{array}$ & $\begin{array}{l}\text { Interpretation of data, critical } \\
\text { revision of manuscript for } \\
\text { intellectual content }\end{array}$ \\
\hline
\end{tabular}

Appendix (continued)

\begin{tabular}{lll}
\hline Name & Location & Contributions \\
\hline $\begin{array}{l}\text { Laurie } \\
\text { Gutmann, }\end{array}$ & $\begin{array}{l}\text { University of lowa, lowa } \\
\text { City }\end{array}$ & $\begin{array}{l}\text { Study concept and design, } \\
\text { analysis and interpretation of } \\
\text { data, drafting and critical } \\
\text { revision of manuscript for } \\
\text { intellectual content }\end{array}$ \\
$\begin{array}{l}\text { Ludwig } \\
\text { Gutmann, } \\
\text { MD }\end{array}$ & City & $\begin{array}{l}\text { Study concept and design, } \\
\text { analysis and interpretation of } \\
\text { data, drafting and critical } \\
\text { revision of manuscript for } \\
\text { intellectual content }\end{array}$ \\
\hline
\end{tabular}

\section{References}

1. Pennisi EM, Arca M, Bertini E, et al. Neutral lipid storage diseases: clinical/genetic features and natural history in a large cohort of Italian patients. Orphanet J Rare Dis 2017;12:90.

2. Jordan $\mathrm{CH}$. The familial occurrence of fat containing vacuoles in the leukocytes diagnosed in two brothers suffering from dystrophia musculorum progressiva. Acta Med Scand 1953;145:419-423.

\section{Call for Voices: Lived Experiences}

The Editors of the Neurology specialty site Equity, Diversity, \& Inclusion encourage you to submit short first-person accounts (1,000 words or less) of experiences lived within the realm of equity, diversity, and inclusion (EDI) with the goal of informing and enlightening our community on these critical issues. Some topics to consider include, but are not limited to:

- Descriptions of personal experiences that shaped your views of EDI.

- Reflections on the intersection between personal identity and career.

- Discussions at the intersection of EDI and neurology patient care, research, education, advocacy, or policy.

Submit your contributions to journal@neurology.org and include "Voices Submission" in the subject line.

\section{Visit the Neurology ${ }^{\circledR}$ Website at Neurology.org/N}

- More article-based content on home pages

- Streamlined menus and navigation

- Enhanced blog sections for specialty areas

- $\quad$ Same experience on desktop, tablet, and mobile devices

- Improved article reading experience; links more evident (pdf, analytics, social media)

- Neurology ${ }^{\circledR}$ Clinical Practice initiative "Practice Current" global surveys will be accessible across sites

f Find Neurology ${ }^{\circledR}$ on Facebook: http://tinyurl.com/neurologyfan

Follow Neurology ${ }^{\circledR}$ on Twitter: https://twitter.com/GreenJournal 


\section{Neurology}

\section{Neutral lipid-storage disease with myopathy and Jordan anomaly \\ Riccardo Zuccarino, Daniel M. Anderson, Carol Holman, et al. Neurology 2020;95;599-600 Published Online before print August 5, 2020 \\ DOI 10.1212/WNL.0000000000010585}

This information is current as of August 5, 2020

\begin{tabular}{|c|c|}
\hline $\begin{array}{l}\text { Updated Information \& } \\
\text { Services }\end{array}$ & $\begin{array}{l}\text { including high resolution figures, can be found at: } \\
\text { http://n.neurology.org/content/95/13/599.full }\end{array}$ \\
\hline References & $\begin{array}{l}\text { This article cites } 2 \text { articles, } 0 \text { of which you can access for free at: } \\
\text { http://n.neurology.org/content/95/13/599.full\#ref-list-1 }\end{array}$ \\
\hline Subspecialty Collections & $\begin{array}{l}\text { This article, along with others on similar topics, appears in the } \\
\text { following collection(s): } \\
\text { All Genetics } \\
\text { http://n.neurology.org/cgi/collection/all_genetics } \\
\text { All Neuromuscular Disease } \\
\text { http://n.neurology.org/cgi/collection/all_neuromuscular_disease } \\
\text { Muscle disease } \\
\text { http://n.neurology.org/cgi/collection/muscle_disease }\end{array}$ \\
\hline Permissions \& Licensing & $\begin{array}{l}\text { Information about reproducing this article in parts (figures,tables) or in } \\
\text { its entirety can be found online at: } \\
\text { http://www.neurology.org/about/about_the_journal\#permissions }\end{array}$ \\
\hline Reprints & $\begin{array}{l}\text { Information about ordering reprints can be found online: } \\
\text { http://n.neurology.org/subscribers/advertise }\end{array}$ \\
\hline
\end{tabular}

Neurology ${ }^{\circledR}$ is the official journal of the American Academy of Neurology. Published continuously since 1951, it is now a weekly with 48 issues per year. Copyright @ 2020 American Academy of Neurology. All rights reserved. Print ISSN: 0028-3878. Online ISSN: 1526-632X.

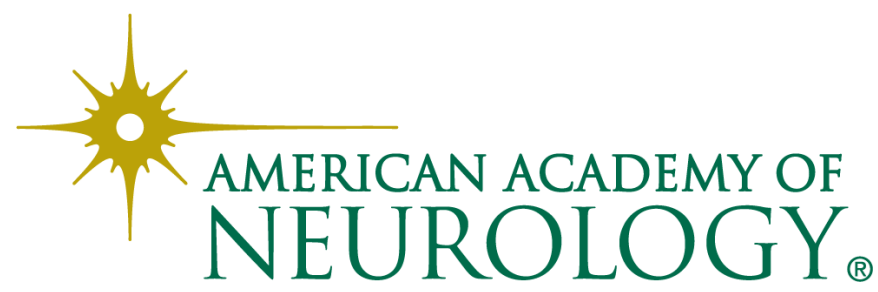

